\title{
Radiocarbon
}

1977

\section{BROOKLYN COLLEGE RADIOCARBON DATES I}

\author{
EVAN T WILLIAMS \\ City University of New York, \\ Chemistry Department, Brooklyn College \\ Brooklyn, New York 11210
}

\section{INTRODUCTION}

This radiocarbon laboratory was established by a grant from Brooklyn College to support the work of its archaeologists and geologists. The method of dating is that of benzene synthesis and liquid-scintillation counting developed by a number of investigators (Noakes et al, 1965; Polach and Stipp, 1967; Tamers, 1975). This list includes nearly all samples processed so far, most of which were done since September 1975.

Samples are examined for obvious contamination and are chemically pretreated as noted in each sample description. If necessary, the sample is soaked in warm $1 \mathrm{M} \mathrm{NaOH}$ to remove humic acids, and rinsed with distilled water until the rinse water is neutral. Then the sample is soaked in warm $1 \mathrm{M} \mathrm{HCl}$ to remove carbonates and rinsed with distilled water and dried under vacuum in a lyophilizing unit. Carbonate samples are treated as noted.

Samples such as wood, charcoal, and peat, are burned in a stream of oxygen, Linde, extra-dry grade. The combustion products are passed over $\mathrm{CuO}\left(\right.$ at $700^{\circ} \mathrm{C}$ ) and through gas-washing bottles containing $\mathrm{KMnO}_{4}$ and $\mathrm{H}_{2} \mathrm{SiO}_{4}$ to remove oxides of nitrogen and sulfur. An oxide of nitrogen, $\mathrm{N}_{2} \mathrm{O}_{3}$, blue solid, brown gas, frequently seen in the liquid-nitrogen trap, has been virtually eliminated by the scrubbers. The $\mathrm{CO}_{2}$ is dried in a trap cooled with dry ice in isopropanol, passed through a tube containing $\mathrm{P}_{2} \mathrm{O}_{5}$ on glass wool and collected in a trap at liquid-nitrogen temperature. If the initial form of the sample is carbonate, $\mathrm{CO}_{2}$ is produced by the action of a mineral acid and is dried and collected as above. The $\mathrm{CO}_{2}$ is then allowed to sublime into storage tanks for measurement of the yield. A small volume of $\mathrm{CO}_{2}$ can be drawn off at this point and reserved for measurements of $\delta^{13} \mathrm{C}$.

Lithium, Li shot, low-sodium, packed under Ar, Lithium Corp America, $25 \%$ in excess of the stoichiometric quantity, is placed in a stainless-steel reaction chamber and heated to $600^{\circ} \mathrm{C}$, pumping all the time through a trap cooled with dry ice. The temperature is measured with a thermocouple in contact with the bottom of the chamber. The $\mathrm{CO}_{2}$ is gradually passed through a dry-ice trap onto the $\mathrm{Li}$, not allowing the indicated temperature to exceed $650^{\circ} \mathrm{C}$. After all the $\mathrm{CO}_{2}$ has re- 
acted, the temperature is raised to $850^{\circ}$ to $900^{\circ} \mathrm{C}$ and the chamber is continuously evacuated through the dry-ice trap for $30 \mathrm{~min}$ to an hour.

After cooling, ca $1 \mathrm{~L}$ of distilled water is slowly added to the $\mathrm{Li}_{2} \mathrm{C}_{2}$. The ensuing $\mathrm{C}_{2} \mathrm{H}_{2}$ is passed through 2 traps cooled by dry ice and then through a column of $\mathrm{P}_{2} \mathrm{O}_{5}$ to a liquid-nitrogen trap. The $\mathrm{H}_{2}$ is pumped off. If fresh $\mathrm{Li}$ is used and conditions are properly controlled, yields of $95 \%$, with respect to the $\mathrm{CO}_{2}$, may be obtained. The effectiveness of the $\mathrm{Li}$ is improved if it is stored under Ar rather than air.

The $\mathrm{C}_{2} \mathrm{H}_{2}$ is now sublimed directly onto the catalyst, in a tube cooled in a water bath. The entire benzene synthesis including set up and clean up can be done in a day.

Once the $\mathrm{C}_{2} \mathrm{H}_{2}$ has been absorbed by the catalyst, the tube is sealed by closing a stopcock and can be stored indefinitely. The tube is heated to $150^{\circ} \mathrm{C}$ for 1 to $2 \mathrm{hr}$ and the $\mathrm{C}_{6} \mathrm{H}_{6}$ is collected in a dry-ice trap.

The catalyst, developed by Noakes and available from TASK, Inc, Oak Ridge, Tennessee, consists of an alumina base impregnated with vanadium in the +5 oxidation state. $25 \mathrm{~g}$ of the catalyst, sufficient for the trimerization of the $\mathrm{C}_{2} \mathrm{H}_{2}$ produced from 12L (STP) of $\mathrm{CO}_{2}$, are heated to 350 to $400^{\circ} \mathrm{C}$ under vacuum through a mechanically refrigerated cold trap at $-50^{\circ} \mathrm{C}$ for a minimum of $4 \mathrm{hr}$ and preferably overnight. The amount of catalyst can be reduced proportionately if the quantity of $\mathrm{CO}_{2}$ is $<12 \mathrm{~L}$. The uptake of $\mathrm{C}_{2} \mathrm{H}_{2}$ by the catalyst, however, will be faster if more catalyst is used.

The results of a brief study of the rate of uptake of $\mathrm{C}_{2} \mathrm{H}_{2}$ by the catalyst and the percent yield of benzene vs the amount of catalyst are shown in Table 1 . The catalyst samples were from the same batch and were all dried at $350^{\circ} \mathrm{C}$ for $18 \mathrm{hr}$. The acetylene was produced by the hydrolysis of $\mathrm{CaC}_{2}$, Fisher, Electrolite grade, 20 to 30 mesh, using the techniques described above for the $\mathrm{Li}_{2} \mathrm{C}_{2}$ hydrolysis.

TABLE 1

Rate of $\mathrm{C}_{2} \mathrm{H}_{2}$ uptake and yield of benzene

\begin{tabular}{cccc}
\hline Catalyst & Time* & Benzene yield & $\%$ yield \\
\hline $25 \mathrm{~g}$ & $45 \mathrm{~min}$ & $5.09 \mathrm{~g}$ & 86 \\
$50 \mathrm{~g}$ & $38 \mathrm{~min}$ & $4.36 \mathrm{~g}$ & 73 \\
$100 \mathrm{~g}$ & $20 \mathrm{~min}$ & $3.57 \mathrm{~g}$ & 60 \\
\hline
\end{tabular}

* Time to absorb 5.5 $\mathrm{L}$ of $\mathrm{C}_{2} \mathrm{H}_{2}$ at 1 atm pressure. $\mathrm{C}_{2} \mathrm{H}_{2}$ pressure kept constant at 1 atm during absorption step.

Benzene for the modern-standard sample is synthesized from $\mathrm{CO}_{2}$ produced in the wet oxidation of NBS oxalic acid. Hot $\mathrm{KMnO}_{4}$ solution is run into a solution of the $\mathrm{H}_{2} \mathrm{C}_{2} \mathrm{O}_{4}$ acidified with $\mathrm{H}_{2} \mathrm{SO}_{4}$. The $\mathrm{CO}_{2}$ produced is dried and trapped as described above. The endpoint of the reaction is easily seen by the change from a clear solution to purplishbrown. 10 to $20 \mathrm{ml}$ more of the $\mathrm{KMnO}_{4}$ solution are added, the solution 
is stirred for a few min, and then it is allowed to boil briefly under vacuum to remove the last traces of $\mathrm{CO}_{2}$ from the solution. Analysis, by Teledyne Isotopes, of the $\mathrm{CO}_{2}$ produced in this method gave a value of $\delta^{13} \mathrm{C}$ equal to $-19.44 \%$ with respect to $\mathrm{PDB}$.

The benzene is transferred to a counting vial and weighed. If the amount of benzene is $<4 \mathrm{ml}$, the difference is made up by adding benzene, Baker Analyzed Reagent, Spectrophotometric grade; if the amount is greater, an appropriate volume is removed. As can be seen by comparing the results of the counts on $4 \mathrm{ml}$ and $0.35 \mathrm{ml}$ of benzene synthesized from Sample BC-7, the result does not depend on the amount of benzene produced except that the relative uncertainty is larger for the smaller amount of benzene. Total volume of the solution is made up to $5 \pm 0.05 \mathrm{ml}$ by adding $1 \mathrm{ml}$ scintillator solution consisting of $50 \mathrm{~g}$ PPO and $2.5 \mathrm{~g}$ bis-MSB in 1L toluene.

Counting vials used are commercially available liquid-scintillation vials of low-potassium glass, modified to a volume of $6 \mathrm{ml}$ and shielded top and bottom by a disk of old lead $7 \mathrm{~mm}$ thick. The cork cap liner is replaced by a Teflon disk and the threads are wrapped with Teflon tape. For all vials used, evaporation of benzene is negligible over the counting period, eg, a modern-standard sample in use for 6 mos lost only $30 \mathrm{mg}$. Background in all vials was measured and, relative to each other, all vials exhibit the same background within an average deviation of $3 \%$. A check of 13 vials counted sequentially over a 4 mos period revealed that each vial had a background relative to the average background for all vials by a factor ranging from 0.932 to 1.07 . Although for most samples the correction for the relative background is nearly negligible, it is applied for all samples.

All samples are weighed before and after counting to check for possible benzene loss. The samples can be stored for later recount and the modern standard and background, the latter, $4 \mathrm{ml}$ Spectrophotometric grade benzene plus $1 \mathrm{ml}$ scintillator solution, samples can be used repeatedly, a considerable saving of time, effort, and NBS oxalic acid.

The counter is a Picker Nuclear Liquimat Model 220 with photomultiplier tubes selected for low noise. The samples, including background and modern standard, are placed in the counter and counted sequentially for $100 \mathrm{~min} /$ count. The cycle is repeated as often as desired with a minimum of 20 cycles, $2000 \mathrm{~min} / \mathrm{sample}$, for each series of determinations. This procedure clearly reveals erroneous 100-min counts and monitors the background continuously during the entire run which may take a week or more.

The constant cycling of the samples has no effect on the respective activities as there is negligible leakage from the vials under the operating conditions. The stability of the system was checked and, as shown in Table 2, was very good.

All samples are checked for quenching by an external ${ }^{137} \mathrm{Cs}$ source and the channels-ratio technique. Quenching is not a problem due to 
TABLe 2

Consistency of counter system. $5 \mathrm{~g}$ benzene solution

\begin{tabular}{lcc}
\hline Counting period & Background $(\mathrm{cpm})$ & $\begin{array}{c}\text { Modern standard } \times 0.95 \\
(\mathrm{cpm} / \mathrm{g} \text { benzene })\end{array}$ \\
\hline $7 / 20-7 / 26 / 75$ & $2.57 \pm 0.05$ & $7.83 \pm 0.05$ \\
$7 / 27-8 / 1$ & $2.40 \pm 0.04$ & $7.86 \pm 0.04$ \\
$8 / 2-8 / 12$ & $2.30 \pm 0.04$ & $7.74 \pm 0.04$ \\
$8 / 13-8 / 18$ & $2.28 \pm 0.05$ & $7.86 \pm 0.05$ \\
$8 / 19-8 / 25$ & $2.17 \pm 0.05$ & $7.77 \pm 0.05$ \\
$9 / 12-9 / 17$ & $2.91 \pm 0.05$ & $7.57 \pm 0.05$ \\
$9 / 18-9 / 24$ & $2.65 \pm 0.05$ & $7.75 \pm 0.05$ \\
\hline
\end{tabular}

the high purity of the benzene. In an initial period of testing, a modernstandard sample in use for 6 mos, suffered ca $2 \%$ decrease of activity. A change in the channels ratio indicated that the problem was quenching; there was no benzene loss. As I had observed that oxygen dissolved in the counting solution would quench the sample, the sample was opened and argon was briefly blown in to displace the air in the vial. This procedure restored the activity and the channels ratio resumed its normal value. Samples are now routinely sealed with an argon atmosphere in the counting vial.

The raw data are scanned for infrequent spurious counts that are discarded. After the respective sample activities are corrected for background and divided by the mass of synthesized benzene, the ratio of the sample activity to that of the modern standard $(\times 0.95)$ is calculated.

The fact that the actual measurements in radiocarbon dating produce an activity ratio rather than an age may be easily overlooked. Although ages are often reported in Radiocarbon to 4 or 5 significant figures, requiring ca $10^{5}$ and $10^{7}$ counts, respectively, the reported uncertainties for some of these ages indicate that the ratio was not actually determined to that degree of accuracy. In this laboratory, the number of significant digits in the reported age is the same as that determined for the activity ratio, generally 3 . The reported uncertainty is a $1 \sigma$ standard deviation based on counting statistics only.

It would seem reasonable to propose that dating labs should report, in this journal, the actual experimentally determined value for the ratio and uncertainty. This procedure would be advantageous in that while the calculated ages as reported are based on a number of assumptions, such as choice of half life and dendrochronologic correction, the ratio has enduring significance and is the basic datum to which one must return if the procedures of calculating age change.

Where desired by the submitter, the age is calculated using the $5730 \mathrm{yr}$ half-life and corrected using the MASCA table (Ralph et al, 1973). Table 3 shows the results of some cross checks. 
TABLE 3

Results of cross checks

\begin{tabular}{|c|c|c|c|}
\hline \multirow[b]{2}{*}{ Sample } & $\begin{array}{l}\text { Measured } \\
\text { age }\end{array}$ & $\begin{array}{l}\text { Our } \\
\text { measurement }\end{array}$ & \multirow{2}{*}{$\begin{array}{l}\text { MASGA } \\
\text { correction }\end{array}$} \\
\hline & \multicolumn{2}{|c|}{ Years BP, $\mathrm{t}_{1 / 2}=5568$} & \\
\hline Charcoal, (U Ga) & $3455 \pm 85$ & $3880 \pm 100$ & - \\
\hline Charcoal, (U Ga) & $540 \pm 55$ & $490 \pm 90$ & - \\
\hline Peat, (SI-1103) & $11,100 \pm 120$ & $9500 \pm 400$ & - \\
\hline Sequoia wood, P-SW-SEQ-2 & $1850-1860$ & $1980 \pm 60$ & $1930 \pm 90$ \\
\hline (6 samples, 10 rings each. & $1708-1718$ & $1570 \pm 60$ & $1550 \pm 80$ \\
\hline Age dendrochronologically & $1466-1476$ & $1680 \pm 60$ & $1670 \pm 100$ \\
\hline determined, see Ralph et al) & $1331-1341$ & $1250 \pm 60$ & $1150-1250 \pm 70$ \\
\hline & $1200-1210$ & $1210 \pm 60$ & $1190-1160 \pm 60$ \\
\hline & $1040-1050$ & $910 \pm 70$ & $900 \pm 90$ \\
\hline
\end{tabular}

\section{ACKNOWLEDGMENTS}

It is a pleasure to acknowledge the support and encouragement of George Gibson who was instrumental in the establishment of this laboratory. Thanks are due John Noakes for his kind assistance and advice. I would like to thank Robert Stuckenrath for helpful discussions and samples for crosschecking and Henry Michael for supplying samples of sequoia wood. I would also like to thank the following undergraduate students for their outstanding contributions to the work: Noel Guardala, Rolf Martin, David Kadko and James Mazzullo.

\section{SAMPLE DESCRIPTIONS}

I. GEOLOGIC SAMPLES

\section{BC-20. Piston Core E-30-71}

$4300 \pm 70$ 2380 BC

Shell (Mulinia sp and Nucula sp) from core sample Delaware Bay, $\left(39^{\circ} 5^{\prime} 20^{\prime \prime} \mathrm{N}, 74^{\circ} 13^{\prime} 70^{\prime \prime} \mathrm{W}\right)$. Water depth $9.4 \mathrm{~m}$, referred to mean low water, depth in core $2.2 \mathrm{~m}$. Sediment matrix was a very fine sandy mud. Coll 1971 by G B Weil, Dept Geol, Brooklyn Coll. Comment (CBW): this core was taken during a study of transgressive sedimentary environments of Delaware Bay. The date falls on Kraft's (1971) sea-level-rise curve for the Delaware coastline and indicates rate of local sediment deposition.

\section{Cave series}

Deposits on cave walls and enlarged joints consisting of a resinous solid containing visible fecal matter and plant fragments. Coll by David Leveson, Dept Geol, Brooklyn Coll. NaOH/HCl pretreatment used. 
BC-21. Canyonland

Coll April, 1972 from wall of cave formed by joint enlargement, Cutler-Rico formation (Permian) Needles Dist, Canyonland Natl Park, $\mathrm{Utah}\left(38^{\circ} 6^{\prime} \mathrm{N}, 104^{\circ} 52^{\prime} \mathrm{W}\right)$.

\section{BC-22. Zion}

$\mathbf{3 8 4 0} \pm \mathbf{5 0}$

Coll April, 1975 from rear of "Pictograph" Cave, Navajo Sandstone, Rock Pasture area of Zion Natl Park $\left(37^{\circ} 10^{\prime} \mathrm{N}, 112^{\circ} 53^{\prime} \mathrm{W}\right)$.

\section{Coles Cave series}

Pleistocene stalactites precipitated on roof of Coles Cave by vadose seepage, Barbados, West Indies (13० $\left.10^{\prime} \mathrm{N}, 59^{\circ} 30^{\prime} \mathrm{W}\right)$. Coll 1966 by W H Harris, Dept Geol, Brooklyn Coll. Samples were growth-layer increments of conical ring stalactites composed of low-magnesium calcite; dimensions refer to distance from original outer surface of stalactite. $\delta^{13} \mathrm{C}$ referred to $\mathrm{PDB}$.

BC-23. Stalactite 3, Layer S1-C

$$
\begin{array}{rl}
\mathbf{7 7 4 0} \pm 140 & \mathbf{5 7 9 0} \mathbf{B C} \\
\delta{ }^{13} \mathrm{C}=-9.66 \pm 0.2 \% &
\end{array}
$$

9 to $17.5 \mathrm{~mm}$. With MASCA correction and zero-age correction (see comment at end of series) age is $\begin{aligned} 3500 & \pm 1700 \\ & -1200\end{aligned}$

BC-24. Stalactite 3, Layer S2-T1

$$
\begin{array}{rl}
\mathbf{5 9 2 0} \pm \mathbf{9 0} & \mathbf{3 9 7 0} \mathbf{\text { BC}} \\
\delta^{18} \mathrm{C}=-9.66 \pm 0.2 \% \text { o }
\end{array}
$$

2.5 to $9 \mathrm{~mm}$. MASCA and zero-age corrected date: $1300 \pm 970$

$$
-700
$$

\section{BC-25. Stalactite 4, Layer S1-3}

$$
10,100 \pm 140
$$
8150 BC

$$
\delta^{13} \mathrm{C}=-8.8 \pm 0.2 \%
$$

14.8 to $39.5 \mathrm{~mm}$. MASCA and zero-age corrected date: $6600 \begin{array}{r}+1700 \\ -1300\end{array}$

BC-26. Stalactite 4, Layer S2-4

8.5 to $36 \mathrm{~mm}$. MASCA and zero-age corrected date: $6400+1700$

BC-27. Stalactite 4, Layer S3-4A

4 to $25 \mathrm{~mm}$. MASCA and zero-age corrected date: $\begin{aligned} 6360 & +2000 \\ & -1500\end{aligned}$. 
General Comment (WHH): by extrapolation of dates of growth rings, a zero-age for stalactites was obtained. This "zero-age", $4700+840$, reflects admixture of fossil carbon that is ${ }^{14} \mathrm{C}$ inactive via limestone dissolution in the vadose zone and bulk atmospheric carbon from when the seepage left the soil zone. If ages are compared with conventional calendar scales, $4700 \mathrm{yr}$ age correction must be subtracted. Corrected dates listed for samples are based on $5730 \mathrm{yr}$ half-life.

\section{Marie-Galante Coral series}

Aragonite coral samples from elev reef terraces on Marie-Galante I., Guadaloupe. The lowest terrace, at +1 to $3 \mathrm{~m}$, is constructional and can serve as a marker of a deglacial event (rising sea level) in the Pleistocene. Coll July, 1974 by N E Pingitore, Jr, Dept Geol, Brooklyn Coll.

\section{BC-28. Coral MG-10}

$30,300 \pm 600$

Surface coral sample, from reef elev $3 \mathrm{~m}$, reef core, in growth posi-

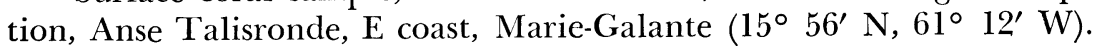

\section{BC-29. Coral MG-14}

$35,000 \pm 2,000$

Surface coral sample, reef elev $3 \mathrm{~m}$, from backreef lagoon sediments. $\mathrm{S}$ coast, due $\mathrm{S}$ of Thibault $\left(15^{\circ} 52^{\prime} \mathrm{N}, 61^{\circ} 16^{\prime} \mathrm{W}\right)$.

\section{BC-30. Coral MG-17}

$31,400 \pm 800$

Surface coral sample, 2nd terrace of I. elev ca $15 \mathrm{~m}$, S coast, MarieGalante, $1 \mathrm{~km}$ E of airport $\left(15^{\circ} 52^{\prime} \mathrm{N}, 61^{\circ} 16^{\prime} \mathrm{W}\right)$.

General Comment (NEP): contamination by more recent carbon may have occurred, but aragonite mineralogy, determined by x-ray diffraction, casts doubts on possibility. If dates are real, they indicate a warming trend (deglacial event) at ca 30,000 BC. Uranium-helium measurements will be made to confirm ages.

\section{BC-39. Caliche-14-16}

Caliche from Odessa, Texas in Permian Basin $\left(31^{\circ} 52^{\prime} \mathrm{N}, 102^{\circ} 23^{\prime} \mathrm{E}\right)$. Stratum, overlying Pleistocene lake deposits, dated at 4000 to $8000 \mathrm{BP}$, based on stratigraphic evidence. Coll March, 1976 by S J Mazzullo, Univ Texas, Permian basin; subm by J M Mazzullo, Brooklyn Coll. Comment (SJM): date indicates reworking of caliche.

\section{ARCHAEOLOGIC SAMPLES}

\section{Susani series}

\section{A. Europe}

Late Bronze Age samples from the Susani site Lugoj, Timis region, Comm Traian, Vulia, Romania $\left(46^{\circ} 20^{\prime} \mathrm{N}, 39^{\circ} 32^{\prime} \mathrm{E}\right)$ (Popescu 1969). Coll 1968 by I Straton, Lugoj Mus, Lugoj, Romania; subm by H A 
Bankoff, Dept Anthropol, Brooklyn Coll. All samples found in a "sanctuary", a round tumulus-like structure of broken earth, with several pits containing burnt organic matter and charred grain. Selected by the excavator, I Staton, to establish chronology of pits and burnt levels. Comment: $\mathrm{NaOH} / \mathrm{HCl}$ pretreatment.

\section{BC-1. Burnt-Level 1, Meter 10$$
3110 \pm 70
$$$$
\text { MASCA corrected date: } 1460-1480+60 \mathrm{BC}
$$

Charcoal from Meter 10 within Burnt-Level 1, assoc with Hallstatt A/B pottery. Date, using $5730 \mathrm{t} \frac{1}{2}: 1250 \pm 70 \mathrm{BC}$.

\section{BC-3. Offering Pit 1}

$$
\begin{array}{ll} 
& \mathbf{3 4 5 0} \pm \mathbf{6 0} \\
& \mathbf{1 5 0 0} \mathbf{\mathrm { BC }} \\
\text { MASCA corrected date }: & 1800 \begin{array}{l}
+240 \\
-80
\end{array}
\end{array}
$$

Carbonized grain within Offering Pit 1, under Burnt-Level 1, assoc with $>100$ single-handled cups of typical Early Hallstatt type. Comment (HAB): probably Hallstatt A, similar to cups from Bobda, Romania. Date, using 5730 t $\frac{1}{2}: 1600 \pm 60$ Bс.

\section{BC-4. Burnt-Level 1, Meter 17-18}

MASCA corrected date: $1690 \pm 90 \mathrm{BC}$ \pm 80 вс.

Burnt wood, Burnt-Level 1, Meter 17-18. Date, using 5730 t $\frac{1}{2}$ : 1470

General Comment (HAB): dates are ca 500 yr earlier than expected, if MASCA correction is applied. Uncorrected dates, using 5730 yr half-life, fit accepted chronology better.

\section{BC-2. Omoljica}

$3530 \pm 80$

\section{$1580 \mathrm{BC}$}

MASCA corrected date: $2050 \pm 70 \mathrm{BC}$

Carbonized grain. Coll by V Karapandzic, Narodni Muz Beograd; subm by $\mathrm{H}$ A Bankoff. Originally coll at Omoljica, Banat, Yugoslavia $\left(44^{\circ} 53^{\prime} \mathrm{N}, 20^{\circ} 40^{\prime} \mathrm{E}\right)$. Sample was found in storeroom of Narodni Muz in a typical 2-handled Pancevo-Omoljica type "beaker" of Middle Bronze (B-C) age date. Inventory No: 344-345. Tested as check for dates from excavated context from Mediana. Date, using $5730 \mathrm{t} \frac{1}{2}$ : $1690 \pm 80$ BC (Trbuhovic, 1967). Comment: $\mathrm{NaOH} / \mathrm{HCl}$ pre-treatment.

\section{Mediana series}

Samples from Late Bronze age site of Brzi Brod, Mediana, near Nis, Yugoslavia $\left(43^{\circ} 20^{\prime} \mathrm{N}, 21^{\circ} 50^{\prime} \mathrm{E}\right)$ (Garasanin, 1969). Coll Aug, 1972 by M V Garasanin, Univ Beograd; subm by $\mathrm{H}$ A Bankoff. Comment: $\mathrm{NaOH} / \mathrm{HCl}$ pretreatment. 
BC-5. Pit 1, LJ XVII

MASCA corrected date: $2050 \pm 70 \mathrm{BC}$

Carbonized wood from center of Pit 1, Lj XVII, 1st level. Date, using $5730 \mathrm{t}_{\frac{1}{2}}: 1690 \pm 60$ BC. Comment (HAB): agrees well with BC-2, supporting Garasanin's placement for lowest level of Mediana in Middle Bronze age (Bronze $\mathrm{C}$ ?). Other dates in this series do not agree.

BC-6. Pit 1, Lj VIII

$3230 \pm 90$

$1280 \mathrm{BC}$

MASCA corrected date: $1570-1600 \pm 80$

Ashes and carbon flakes from area in front of LBA construction, Lj, VIII, Pit 1, No. 65 E 4.00. Date, using 5730 t $\frac{1}{2}: 1370 \pm 90$ BC.

\section{BC-7. Pit 2, Lj XVIII}

$$
\begin{array}{cc} 
& 3940 \pm 40 \\
& 1990 \mathrm{BC} \\
& \\
2560 & +30 \\
& -70
\end{array}
$$

Wood (oak) from bottom of Pit 2, Lj XVIII. Date, using $5730 \mathrm{t} \frac{1}{2}$ : $2110 \pm 40$ BC. Comment: sample, comprised of $4 \mathrm{ml}$ synthesized benzene, $+1 \mathrm{ml}$ scintillator solution. A 2nd sample was made from $0.3 \mathrm{ml}$ synthesized benzene, left over after $4 \mathrm{ml}$ was taken, $+3.7 \mathrm{ml}$ inert benzene and counted. Age of BC-7, determined using latter sample, was $3800 \pm 200$ BP agreeing well with above.

BC-8. Pit 1, Lj XVII

$$
\begin{aligned}
& 3000 \pm 200 \\
& 1000 \text { BC } \\
& \text { MASCA corrected date: } 1300 \stackrel{+200}{-300} \mathrm{BC}
\end{aligned}
$$

Charcoal, center of Pit 1, Lj XVII. Date, using 5730 t $\frac{1}{2}: 1100 \pm 200$ BC.

BC-9. Lj XVI

$3650 \pm 80$

$1700 \mathrm{BC}$

MASCA corrected date: $2120-2140 \pm 40 \mathrm{BC}$

Oak, pit under the object, Lj XVI. Date, using $5730 \mathrm{t} \frac{1}{2}: 1800 \pm 80$ BC.

\section{BC-10. Pit 1, Lj XVIII}

$3260 \pm 100$ 1310 BC

MASCA corrected date: $1600-1640 \pm 100$

Charred wood from interior of Pit 1, Lj XVIII. Date, using $5730 \frac{1}{2}$ : $1410 \pm 100$ BC.

General Comment (HAB): MASCA-corrected dates run several centuries earlier than chronology based on considerations such as ceramic typology.

BC-42. Log Boat

$250 \pm 100$

Wood. Hollowed $\log$ boat from Sava $\mathrm{R}$ bed at depth $4 \mathrm{~m}$. Coll by Edward Ochsenschlager during investigation of Roman site; Sirmium, near Sremska Mitrovica, Yugoslavia $\left(44^{\circ} 55^{\prime} \mathrm{N}, 19^{\circ} 35^{\prime} \mathrm{E}\right)$. Comment: 
$\mathrm{NaOH} / \mathrm{HCl}$ pretreatment. Comment (EO): date rules out Neolithic or Roman origins.

\section{Head rest series}

$$
\text { B. Egypt }
$$

Two wooden headrests in Egyptian coll of Brooklyn Mus. Subm by Robert Bianchi, Brooklyn Mus for authentication and confirmation of age based on stylistic analysis. Samples drilled from bottom.

BC-40. BM No. 05.325

$$
\begin{aligned}
& \mathbf{4 0 0 0} \pm \mathbf{7 0} \\
& \mathbf{2 0 5 0} \mathbf{B C} \\
& \\
2600 & +200 \\
& -80
\end{aligned}
$$

Wood headrest from Egypt, context unknown. Date, based on 5730 $\mathbf{t} \frac{1}{2}: 2160 \pm 70$ Bc. Comment (RB): either of dates based on $5730 \mathrm{t} \frac{1}{2}$ and MASCA correction agree with our date based on stylistic analysis which places object in Old Kingdom, 2686 to 2181 BC.

BC-41. BM No. 37.443E

$2710 \pm 80$

$760 \mathrm{BC}$

$M A S C A$ corrected date: $900 \pm 110 \mathrm{BC}$

Wood headrest from Egypt from coll of Henry Abbott, known to be from Saqqara, context unknown. Date, based on $5730 \mathrm{t} \frac{1}{2}: 830 \pm 80 \mathrm{BC}$. Comment (RB): date, based on stylistic analysis, is 1200 to $1100 \mathrm{BC}$.

\section{Old Fort series}

\section{United States}

Samples from a site investigated to find evidence for an old fort built by Esopus Indians and later razed by the Dutch in retaliation for a massacre, Ulster County, NY, (41 $31^{\circ} 37^{\prime \prime}$ N. $74^{\circ} 15^{\prime}$ W.) Coll, Aug, 1972 by H D Winters and I A Berman, New York Univ. Charcoal from layer of yellow sand above culturally sterile layer, presuming earliest occupation of site.

\section{BC-35. Feature 17a}

$4200 \pm 100$

Charcoal, $56 \mathrm{~cm}$ below surface, Feature $17 \mathrm{a}$, hearth. Comment: no pretreatment.

BC-36. Feature 17a

$4130 \pm 90$

2180 BC

Charcoal, same as BC-35. Comment: $\mathrm{NaOH} / \mathrm{HCl}$ pretreatment. Good agreement with BC-35.

\section{BC-38. Feature 7a}

$3980 \pm 50$

Charcoal, Feature 7a, hearth pit. Comment: $\mathrm{NaOH} / \mathrm{HCl}$ pretreatment.

General Comment (IAB): No evidence found for fort; based on typological comparisons, projectile-point types, etc and above dates, site is probably "Archaic." 


\section{REFERENCES}

\section{B C I}

Garasinin, M V, 1969, Die prahistorische siedlung Brzi Brod bei Nis und das problem des Spät Bronze zeitlichen Mediana-gruppen: Archaeologia Iugoslovia, v 10, p 85-90.

Kraft, J C, 1971, Sedimentary facies patterns and geologic history of a Holocene marine transgression: Geol Soc America Bull, v 82, p 2131-2158.

Noakes, J E, Kim, S M, and Stipp, J J, 1965, Chemical and counting advances in liquid scintillation age dating: 8th internatl conf on radiocarbon and tritium dating Proc, Pullman, Washington, 1965, p 68-92.

Polach, H A and Stipp, J J, 1967, Improved synthesis for methane and benzene radiocarbon dating: Jour Applied Radiation Isotopes, v 18, p 359-364.

Popescu, D, 1969, Les fouilles excavation archeologiques dans la republic socialiste de Roumania en 1968: Dacia, ns 13, p 507-537.

Ralph, E K, Michael, H N, and Gruninger, J Jr, 1965, University of Pennsylvania dates VII: Radiocarbon, v 7, p 179-186.

Ralph, E K, Michael, H N, and Han, M C, 1973, Radiocarbon dates and reality: MASCA Newsletter, Univ Pennsylvania, v 9, no. 1, p 1-20.

Tamers, M A, 1975, Chemical yield optimization of the benzene synthesis for radiocarbon dating: Jour Applied Radiation Isotopes, v 26, p 676-682.

Trbuhovic, V, 1967, Neka ravmatranja o stratigrafiji na naselgima Bronzanog doba u Vojvodini: Starinar, ns 18, p 175-180. 